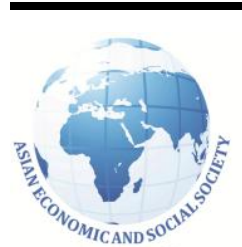

AESS
Journal of Asian Business Strategy

http://www.aessweb.com/journals/5006

DOI: $10.18488 /$ journal.1006/2015.5.7/1006.7.125.131

\title{
INNOVATION CAPABILITY: THE ROLE OF ISLAMIC WORK ETHICS
}

\author{
Muhammad Farrukh \\ SEGi University, Malaysia
}

Sonia Butt

Bahauddin Zakariya University, Pakistan

Shaheen Mansori

INTI International University, Malaysia

\section{Article History:}

Received: 13 May 2015

Revised received: 16 June 2015

Accepted: 9 July 2015

Online available: 11

August 2015

Keywords:

Islamic work ethics, innovation capability

\begin{abstract}
The aim of this research is to investigate the association between Islamic work Ethics (IWE) and innovation capability. The association between Islamic work ethics (IWE) and innovation capability was assessed with the help of valid questionnaire. A total number of 150 questionnaires were distributed out of which 120 were received back. The empirical results show a positive relationship between IWE and innovation capability. This research is expected to underpin the insight into the determinants of innovation capability.
\end{abstract}

\section{INTRODUCTION}

Every culture has a set of unique and influential conditions that affect people's life; especially the culture with religious background has more impact on people's ethical behavior and thoughts (Porter, 2010). According to Quddus et al. (2009) people's religious beliefs affect their understanding of ethics, thus, people portray their beliefs and thoughts in practicing and understanding the ethics in routine life. From last few decades research on ethics has become one of the tinted are of research for the researchers and practitioners. A ton of research is carried out western countries pertaining to work ethics and outcomes.

Most of studies related to work ethics are originated from USA and Europe. A few number of researches are carried out in non-western work environment, and studies concerning to IWE and its inference in work place are very rare (Rokhman, 2010; Kumar \& Rose, 2010, Ahmad, 2011).

Most of the prior studies investigated the role of Islamic work ethics (IWE) on human resource management practices such as, commitment, change management, employee job satisfaction and intention to quit (Yousef, 2001; Rahman et al., 2006; Mohamed et al., 2010; Rokhman, 2010; Haroon

Corresponding author's

Name: Muhammad Farrukh

Email address: mfarrukhiqbal@hotmail.com 
et al., 2012), firm performance (Abbasi et al., 2012) and innovation (Kumar \& Rose, 2010; Awan and Akram, 2012; Abbasi et al., 2012).

The gap in literature regarding IWE implication in work place, becomes the base of this study, Moreover, there are very few studies on the association between IWE and innovation capability. Therefore, the aim of this research is to analyze the relationship between IWE and innovation capability of employees. Taking into consideration of innovation capability for the successful performance of organization, this research is expected to underpin the insight into the innovation capability determinants which can help practitioners to enhance company performance.

\subsection{Islamic work ethics}

Arguments presented by Porter (2010) suggest that the meaning of work in any person's life depends upon the specified history and terms and conditions of his culture. It's not the culture alone which shapes the ethical mindset and behaviour; it is also accompanied by the religious background of the people. It has been noticed by Quddus et al. (2009) that the moral standards and ethical perceptions of people come from the views of their religion's background and values. Hence, what people understand from the term "ethics" and how they implement it in their routine and business life depicts their religious thoughts, morals and beliefs. Islamic work ethics is not a new concept; it has been originated for more than 1400 years. Its written evidence in Quran and been demonstrated by the sayings and actions of the Prophet Muhammad (Ali \& Al-Owaihan, 2008: Rice, 1999).

Ahmad (2011) has made his contribution in finding that Islamic work ethics (IWE hereafter) is a multi-dimensional phenomenon including various dimensions related to economy, society and morality. According to Jalil et al. (2010), Ethics is a condition of being respectful and the enactment of good actions, also named as haya in Islamic terminology. Islamic ethics should be visibly depicted from each and every part of his or her life not only business but personal also. It has been explained by Ali and Al-Owaihan (2008) that the involvement and participation of the employees who believe is determined and affected by IWE at the workplace. Business ethics defined by (Bassiouni, 1993, cited in Wilson, 2006) from Islamic perspective is a relationship of honesty and trust between employers and employees that indicates their spiritual equality before GOD regardless of their materially inequality and the certitude that they are all brothers and sisters. Referring to Ali (2005), the IWE value comprises of four basic principles. The principles are competition, efforts to achieve, transparency, and sense of responsibility towards the moral conduct. All of these principles together formulate a social contract and the focal point is achieving goals of the organization (Ali, 2005). The Islamic work ethics has been gone through both qualitative and quantitative studies from much different point of views. Previous researches investigated Islamic work ethics from human resource management perspective such as organizational commitment (Yousef, 2001; Othman et al., 2004; Rahman et al., 2006) and job satisfaction (Rokhman, 2010). Only a few researchers focused on the relationship of Islamic work ethics and innovation capability.

According to Alhyasat (2012) there are two types of Islamic work ethics dimensions, one type of dimension has significant association with organizational citizenship behaviour while other don't have any such association. Former type of dimension of Islamic work ethics includes affection and tolerance with employees and clients, compliance to the people in power and honour job ethics, and the later includes professionalism and skills, guiding and counselling other Muslims, right use of authority, equality and honesty, uprightness and employee synergy. Yousef (2001) has searched out that there is a positive relationship between Islamic work ethics, engagement and employee sensitivity toward change.

Contrary to this, employee engagement acts as a liaison between Islamic work ethics and employee sensitivity toward change. It has been proved from the results of Haroon et al., (2012) study that there is a positive impact of Islamic work ethics on the nurses working in private hospitals regarding job satisfaction. Similarly another study has reported that commitment can be achieved through the Islamic management ethics (Salem \& Agil, 2012). Kumar and Rose (2010) have found a positive correlation between Islamic work ethics and innovation capability. Similarly, Abbasi et al. (2012) 
reported that learning, innovation and organizational performance can be positively influenced by Islamic work ethics. It has been proved through a research conducted on public sector organizations by Awan and Akram (2012) that Islamic work ethics has a dominant favourable relation with potential of innovation and in addition this relationship is supported through knowledge sharing. Very few studies have been conducted regarding the concept and implementation of Islamic work ethics on sole and organizational process and its consequences, the study under consideration is supposed to make important addition to the studies regarding the topic.

\subsection{Innovation and innovation capability}

Van (1986) defines innovation as not only developing but also implementing of the novel ideas/practices. According to Oslo (2005) innovation is nothing other than implementing new and significant improvements in product (good or service), marketing strategies, the business operations, and managing relations outside the organization. Innovation is one the fundamental factors to create distinctive competitive advantage for organizations (Calantone et al., 2002; Knight \& Cavusgil, 2004; Günday et al., 2009). Drucker (1954) advocated that innovative capability can help an organization to get competitive advantage.

The above mentioned definitions of innovations lead us to four basic elements of innovation which are new concepts, people, processes and institutional context. Innovation is a strategic process in which new ideas, processes, products, or services are generated, accepted, and implemented (Calantone et al., 2002). Going towards innovation capability, Burgelman et al. (2004) has defined that innovation capability is the characteristics of any organization which support and facilitate the innovation strategies of the organization. While according to Neely and Hii (1998) innovative capacity is the potential or degree of any firm, region or a nation of generating innovative outputs which may be product, process, marketing idea or workplace ethics.

The more the potential of producing innovative outputs the more will be the innovative capacity. Lawson and Samson (2001) have given a slightly modified definition of innovation capability which is the ability of any firm how continuously and effectively transforms its generation of ideas into implementation. It is the conversion of concepts and thoughts into new outputs, processes and systems for the betterment of the firm and its stakeholders. Innovation capability is a value creating phenomenon in different areas of the organization such as offering new products either tangible or intangible, being more responsive and willingness to changing trends and policies, exploiting new ideas, being highly learning organization, and increasing the level of competition in a highly competitive and dynamic business atmosphere (Neely \& Hii, 1998; Terziovski, 2007; Shan \& Zhang, 2009). Various factors both internal and external are related to innovation capability and they affect it (Bullinger et al. 2007; Yeşil \& Kaya, 2012). Neely and Hii (1998) has reported three sets of factors that are directly related to, and effect the innovative capability of the organization which are the characteristics of the organization, management and environment. The purpose of this study is to find out that whether there is any association between managerial Islamic work ethics values and innovation capability or not.

\subsection{Islamic work ethic and innovation capability}

The relationship between work ethics and organization's performance has been studied by many researchers. Prior studies show that work ethics a positive impacton both individual and organizational outcomes. Individual outcomes include job satisfaction, loyalty and organizational brotherhood attitude (Koonmee et al., 2010; Sabir et al., 2012) while organizational outcome is the performance of the firm and its position at product life cycle (Berrone et al., 2007; Donker et al., 2008; Sabir et al. 2012).

Jalil et al. (2010) reported that organizational functioning and well-being can be achieved in a much better way through ethical practices and implementation. Further argument leads that ethic-based organizations have high level of job satisfaction and positive personnel well-beings. Employees are more committed and better understand their responsibilities towards the organization. Luthans (2002) has shown many references of the several studies whose results show that a significant positive 
relationship exists between business ethics and outcomes of the organization. Organizational innovativeness is the foremost requirement for any organizations to survive in today's highly predatory and dynamic environment (Neely \& Hii, 1998; Calantone et al., 2002; Terziovski, 2007).

The capability of innovation can be polished through Islamic work ethics values of the organizations (Abbasi et al., 2012; Awan \& Akram, 2012; Kumar \& Rose, 2010). Abbasi et al. (2012) has reported that the integration of Islamic work ethics values into the organizational culture and values help organization to get better return from their human resources. The Islamic work ethics values of the managers act as a role model for the employees and encourage exerting extra effort, novelty, trustworthiness, loyalty to duty and organizations, and good relations among the employees. Jalil et al. (2010) has proposed that certain qualities such as integrity, honesty, solidarity, commitment and responsiveness can be implicated and strengthened by sharing Islamic ethical practices throughout the globe Moreover, some recent studies show a relationship between Islamic work ethics and organizational innovation (Abbasi et al., 2012). It has been reported in public sector organizations by Awan and Akram (2012) that capability of innovation is significantly and positively affected by Islamic work ethics. Therefore, to get the more clear picture of the relationship between Islamic work ethics and innovation capabilities the following hypothesis has been developed;

H: There is a significant relationship between Islamic work ethics values and innovation capabilities

\section{METHODOLOGY}

English version of the questionnaire was designed based on the previous scales used for the variables understudy. A total number of 150 questionnaires were disseminated among the employees of telecommunication companies in Lahore, Pakistan. 120 questionnaires were returned back by the respondent and the response rate was $80 \%$.all the items of scale were rated on five point likert scale. Regression analysis was done by the help of SPSS 19.The target of the regression analysis is to predict the dependent variable through the values of independent variable, in this study the Innovation Capability is being predicted with the help of Islamic work ethics value

Table 1: Reliability and normality test

\begin{tabular}{lcccccc}
\hline Variable & $\mathbf{N}$ & Number of Items & Cronbach's Alpha & M & SD & SE \\
\hline Islamic work ethics & 120 & 17 & 0.80 & 4.33 & 0.29 & 0.04 \\
Innovation capability & 120 & 5 & 0.72 & 3.47 & 0.56 & 0.05 \\
\hline
\end{tabular}

\section{RESULTS AND DISCUSSIONS}

The above table (table 1) shows the mean SD and SE in mean of the variables understudy. The mean score of IWE is $4.33 \mathrm{SD}$ is 0.29 and SE is 0.04 . Mean for innovative capability is $3.47 \mathrm{SD}$ and SE is $0.56 \& 0.05$ respectively.

Above table shows the results of the pearson's correlation between the variables of the study.It is clear from the above table that IWE is positivly correlated with the innovation capability $(\mathrm{R}=0.65, \mathrm{p}<$ $0.001)$.

Table 2: Regression analysis of Islamic work ethics and innovation capability

\begin{tabular}{lccccc}
\hline Variables & \multicolumn{2}{c}{ Adjusted } & T value & \multicolumn{2}{c}{ Significance } \\
Islamic work ethics and & Beta & R square & & P value & F \\
Innovation capability & $0.65^{* * *}$ & 0.4 & 8.30 & 0.000 & $68.68^{* * *}$ \\
\hline
\end{tabular}

Note: $* \mathrm{p}<0.05, * * \mathrm{p}<0.01, * * * \mathrm{p}<0.001$

The results of regression analysis in table 3 show that Islamic work ethics has a positive impact on innovative capability (As beta value is $0.65, \mathrm{p}<0.001$ ). So, these results confirmed that "There is positive relationship between Islamic work ethics and innovation capability. 


\section{DISCUSSION AND IMPLICATION}

The purpose of this research was to investigate the relationship between Islamic work ethics and innovative capability. The findings of the study showed a positive and significant relationship between these two variables of the study. The significance of the study is twofold, first it added knowledge in the domain of Islamic work ethics and innovative capability, and second the findings will help the practitioners to appreciate the delegation of IWE in designing, formulating and implementing the change programe in organizations. Ethics in the workplace is important and no one can afford to avoid it whether work ethic is Islamic or other religions based.

\subsection{Limitations and future recommendations}

This study is subject to some limitations. This study was confined to only one city and a small sample size. It is recommended to use a large sample to enhance the generalizability of the study.

It is also recommended to test a mediating or moderating relationship between IWE and innovation capability. Furthermore, a cross national study using relatively a large sample is highly recommended to compare and assess the generalizability of this research.

\begin{tabular}{|l|}
\hline Funding: This study received no specific financial support. \\
\hline Competing Interests: The authors declare that they have no conflict of interests. \\
\hline Contributors/Acknowledgement: All authors participated equally in designing and estimation of current \\
research. \\
\hline $\begin{array}{l}\text { Views and opinions expressed in this study are the views and opinions of the authors, Journal of Asian Business } \\
\text { Strategy shall not be responsible or answerable for any loss, damage or liability etc. caused in relation to/arising } \\
\text { out of the use of the content. }\end{array}$ \\
\hline
\end{tabular}

\section{References}

Abbasi, A. S., Ghulam, M. M., \& Muzammil, H. (2012). Islamic work ethics: How they affect organizational learning, innovation and performance. Actual Problems of Economics, 138(12), 471-280.

Ahmad, M. S. (2011). Work ethics: An Islamic prospective. International Journal of Human Science, $8(1), 851-859$.

Alhyasat, K. M. K. (2012). The role of Islamic work ethics in developing organizational citizenship behaviour at the Jordanian press foundations. Journal of Islamic Marketing, 3(2), 139-154.

Ali, A. J., \& Al-Owaihan, A. (2008). Islamic work ethic: A critical review. Cross Cultural Management: An International Journal, 15(1), 5-19.

Ali, J. A. (2005). Islamic perspectives on management and organization. UK: Edward Elgar Publishing.

Awan, K. Z., \& Akram, M. (2012). The relationship between Islamic work ethics and innovation capability and knowledge sharing plays moderation role. International Journal of Economics and Management Sciences, 1(8), 34-48.

Bassiouni, M. C. (1993). Business ethics in Islam. In: Paul M. Minus, editors. In The Ethics of Business in a Global Economy. Dordrecht: Kluwer Academic, 117-122.

Berrone, P., Surroca, J., \& Tribo, J. A. (2007). Corporate ethical identity as determinant of firm performance: A test of the mediating role of stakeholder satisfaction. Journal of Business Ethics, 76(1), 35-53.

Bullinger, H. J., Bannert, M., \& Brunswicker, S. (2007). Managing innovation capability in SMEs. Tech Monitor, Special Feature: Innovation \& KM by SMEs, May-June, 17-27.

Burgelman, R. A., Christensen, C. M., \& Wheelwright, S. C. (2004). Strategic management of technology and innovation. Boston: McGraw-Hill.

Calantone, R. J., Cavusgil, S. T., \& Zhao, Y. (2002). Tacit knowledge transfer and firm innovation capability. Journal of Business Industrial Marketing, 18(1), 6-21.

Donker, H., Poff, D. \& Zahir, S. (2008). Corporate values, Codes of ethics and firm performance: A Look at the Canadian context. Journal of Business Ethics, 82, 527-537. 
Drucker, P. F. (1954). The practice of management. New York: Harper and Row Publishers.

Günday, G., Ulusoy, G., Kılıç, K., \& Alpkan, L. (2009). Effects of innovation types on firm performance. International Journal of Production Economics, 133(2), 662-676.

Haroon, M., Zaman, H. M. F., \& Rehman, W. (2012). The relationship between Islamic work ethics and job satisfaction in healthcare sector of Pakistan. International Journal of Contemporary Business Studies, 3(5), 6-12.

Jalil, A., Azam, F. \& Rahman, M. K. (2010). Implementation mechanism of ethics in business organizations. International Business Research, 3(4), 45-151.

Knight, G. A., \& Cavusgil, S. T. (2004). Innovation, organizational capabilities, and the born-global firm. Journal of International Business Studies, 35, 124-141.

Koonmee, K., Singhapakdi, A., Virakul, B., \& Lee, D. J. (2010). Ethics institutionalization, quality of work life, and employee job-related outcomes: A survey of human resource managers in Thailand. Journal of Business Research, 63(1), 20-26.

Kumar, N. R., \& Rose, R. C. (2010). Examining the link between Islamic work ethic and innovation capability. Journal of Management Development, 29(1), 79-93.

Lawson, B., \& Samson, D. (2001). Developing innovation capability in Organisations: A dynamic capabilities approach. International Journal of Innovation Management, 5(3), 377-400.

Luthans, F. (2002). Organizational behaviour. Boston: McGraw-Hill.

Mohamed, N., Karim, N. S. A., \& Hussein, R. (2010). Linking Islamic work ethic to computer use ethics, job satisfaction and Organizational commitment in Malaysia. Journal of Business Systems, Governance and Ethics, 5(1), 13-23.

Neely, A., \& Hii, J. (1998). Innovation and business performance: A literature review. The judge institute of management studies university of Cambridge, Retrieved from http://ecsocman.hse.ru/data/696/521/1221/litreview innov1.pdf.

Oslo, M. (2005). The measurement of scientific and technological activities: Guidelines for collecting and interpreting innovation data, $3 r d$ ed. Organization for economic co-operation and development statistical office of the European communities.

Othman, A. S. S., Rahman, N. M. A., Malek, Z. A., \& Osman, A. R. (2004). Organizational Commitment and work ethics: An empirical assessment in a Malaysian context. Retrieved from http://faculty.kfupm.edu.sa/coe/sadiq/proceedings/SCAC2004/30.ASC041.EN.Othman.

Organizational\%20Commitment\%20and\%20Work\%20E\%20_1_.pdf.

Porter, G. (2010). Work ethic and ethical work: Distortions in the American dream. Journal of Business Ethics, 96(4), 535-550.

Quddus, M., Bailey, III. H., \& White, L. R. (2009). Business ethics: Perspectives from Judaic, Christian, and Islamic scriptures. Journal of Management Spirituality Religion, 6(4), 323-334.

Rahman, N. M., Muhamad, N., \& Othman, A. S. (2006). The relationship between Islamic work ethics and Organizational commitment: A case analysis. Malaysian Management Review, 41(1), 25-35.

Rice, G. (1999). Islamic work ethic and the implication for the business. Journal of Business Ethic, $18,345-358$.

Rokhman, W. (2010). The effect of Islamic work ethics on work outcomes. Electronic Journal of Business Ethics and Organization Studies, 15(1), 21-27.

Sabir, M. S., Iqbal, J. J., Rehman, K. U., Shah, K. A., \& Yameen, M. (2012). Impact of corporate ethical values on ethical leadership and employee performance. International Journal of Business and Social Science, 3(2), 163-171.

Salem, Z. O., \& Agil, S. O. S. (2012). The effects of Islamic management ethics on organizational commitment of employees in Libyan public banks. Australian Journal of Basic and Applied Sciences, 6(7), 260-270.

Shan, W., \& Zhang, Q. (2009). Extension theory and its application in evaluation of independent innovation capability. Kybernetes, 38(3/4), 457-467.

Terziovski, M. (2007). Building innovation capability in organizations: An international cross-case perspective. Imperial College Press, London.

Van-de, V. A. H. (1986). Central problems in the management of innovation. Management Science, 32, 509-607.

Wilson, R. (2006). Islam and business. Thunderbird International Business Review, 48(1), 109-123. 
Yeşil, S., \& Kaya, A. (2012). Exploring the link between innovation capability and financial performance. International Journal of information Technology and Business Management, 6(1), 11-25.

Yousef, D. (2001). Islamic work ethic: A moderator between organizational commitment and job satisfaction in a cross-cultural context. Personnel Review, 30(2), 52-69. 